\title{
インフォームド・コンセントの生い立ちと IRBのあり方
}

\author{
星 野 一 正*
}

【はじめに】

最近、わが国でもインフォームド・コンセント という言葉を、一種の流行語のように人々が口に されるようになったが、その反面、インフォーム ド・コンセントについての勝手な解釈が乱れ飛ん で、混乱を招いているように思えてならない。そ こで、今回は、インフォームド・コンセントとい う用語が使われ始めた時にさかのぼり、歴史的背 景から実務上の意義についてまで述べたいと思う。

\section{【インフォームド・コンセントの確立までの経過】}

インフォームド・コンセントという法的用語が、 世界で初めて使われたのは、アメリカのカリフォ ルニア州控訴裁判所における 1957 年の「サルゴ 裁判」の判決であった。

制定法制度の日本と異なり判例法 (common law) 制度のアメリカでは 20 世紀の初めから『危険性 がある医学的侵襲を含む医療行為を、患者の同意 を得ずに実施して訴えられた場合には、医師が assaultand battery(暴行)の罪で罰せられる』と いう法理が法制化されないままで、長年適用され

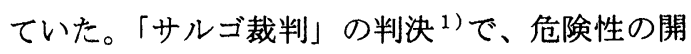
示が論じられる中で、インフォームド・コンセン トという法的用語が初めて使用された。1960 年 のアメリカ・カンサス州最高裁判所におけるナタ

* 京都大学名誉教授, 京都女子大学宗教文化研究所, 国 際バイオエシックス研究センター

厂 605-8501 京都市東山区今熊野北日吉町 35
ンソン裁判の判決 ${ }^{2}$ )では negligence(過失) の法 理がインフォームド・コンセントの法理に加えら れた。以後、1960 年代の医療過誤裁判でさらに 法理が追加され、1970 年ころまでに、インフォ ームド・コンセントの法理は確立されたのであっ た。

\section{【1960 年代の患者の人権運動による影響】}

患者に対して「知らしむべからず依らしむべし」 という医師の権威的独善的な態度に不満と不安を 感じた庶民が、1960 年代に入ってから「患者の 人権運動」を起こし、医師と患者の人間関係の改 善を求めた。この運動を支援しようと病院の礼拝 堂の牧師をはじめ多くの宗教家、哲学者、倫理学 者、法律家などがどのようにしたら患者たちが求 める医師との人間関係ができるかを学際的に研究 を始めた。従来の「ヒポクラテスの誓い」の医師 に都合のよい解釈がいけなかったとし、患者中心 の新しい倫理が模索され始めた。従来の医療過誤 裁判で使っていた「ヒポクラテスの踅い」を倫理 的基準とした裁判基準が使えなくなり、「ニュー ルンベルグ倫理網領 1947 年」を倫理基淮とした 裁判基準が、インフォームド・コンセントの法理 に加えられて確立されていったが、その過程で、 1966 年に Dr. Henry Beecher が、一般病院の患 者が知らない内に人体実験の被験者とされていた 実例を挙げて論文を発表したので、「患者の人権 運動」はいやが上にも盛り上がり、インフォーム ド・コンセントも充実していった。1969 年には、 
新しく生まれつつあった生命倫理学のための研究 所として「ヘイスチング・センター」が設立され、 1971 年には「ケネディ倫理研究所」が設立され た。その頃、この学問のために英語の新語が創ら れて bioethics と命名された。

\section{【インフォームド・コンセントの法理の内容】}

インフォームド・コンセントの重要性は、医師 が患者に、病状をよく説明して理解して兌った上 て、今後の検査や治療法について複数の可能な選 択肢を出して、患者が比較検討できるように説明 し、それぞれの選択肢に内在する危険性を伴う医 学的侵襲について分かり易く理解できるように説 明し、医師が説明した範囲内での危険性が含まれ ている医療であることを患者が納得した上で、そ の医療を受けることに自主的に同意する必要があ る。もしそのような内容の同意をして貪わなけれ ば、医師は、患者に故意の傷害を与えたとして罰 せられる。医師が合法的に患者に医療行為ができ るためには、危険性を含む医療を受けるという患 者の同意が必須条件である。

しかし、現在わが国の識者たちには、インフォ ームド・コンセントにおけるコンセント、同意、 の真の法的意味を知らないで発言している方が多 過ぎるように思えて、心配でならない。

\section{【IRB の生い立ち】}

アメリカで患者の人権運動が盛んであった 1966 年に、前述したように、Dr. Beecher が、一般病 院で行われていた非倫理的な医療行為の実例を挙 げた論文を発表した際に、ことの重大さに驚いた アメリカ政府は、NIH を通じて、連邦政府から研 究費を鿓っている病院等では、ヒトを対象とした 医学的研究実施前に、計画書を施設内番査委員会 (Institutional Review Board: IRB)に提出させ、 政府の倫理基準や法律などに抵触せず、被験者の 自主的同意がある場合のみ実施してよいという通 達を出したのが、IRB 設置の始めである。

わが国の医系大学や大きな病院などに自主的に 設置されている倫理委員会は、アメリカにおける 病院倫理委員会 (Hospital Ethics Committee) と
同じような委員会であり、IRB とは異質の委員会 である。アメリカの病院倫理委員会の発祥は、IRB より約 10 年遅く、1976 年のニュージャージー州 最高裁判所における「カレン・アン・クインラン

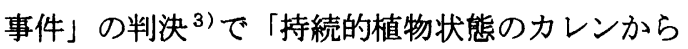
生命維持装置を取り外してよいが、取り外しを決 定する前に、病院倫理委員会の意見を徴するべき である」と裁判官が述べたことに端を発して、ア メリカの多くの病院で自主的に設置し始めたもの である。

わが国では、1982 年に最初の病院倫理委員会 が設置されたが、それ以前に「医薬品の治験委員 会」は機能していた。現在、この「医楽品の治験 委員会」が日本において IRB と呼ばれており、厚 生省の新 GCP に基づいて重要な役割を果たしてき ていることは、臨床薬理学の専門家の熟知されて いるところである。

【IRB におけるインフォームド・コンセントの 特色】

治験における IRB でもインフォームド・コンセ ントは、極めて重要である。ヒトを対象として実 施する医薬品の治験は一種の人体実験であり、そ の上、医薬品の治験ではプラシーボを使った二重 盲検法についてのインフォームド・コンセントに よる被験者の自主的同意・コンセントが必須であ るからである。

世界医師会が採択した「ヘルシンキ宣言 1975 年東京修正」には、「医学の進歩は、研究の一環 として最終的には、ヒトにおける実験結果に依存 しなければならない」と述べてあり、医薬品の治 験の必要性と重要性も暗示してある。しかし、ニュ ールンベルグ倫理綱領の第一条に「医学的研究に おいては、その被験者の自発的同意が本質的に絶 対に必要である」と強調していることを忘れては ならない。

\section{【文献】}

1)星野一正:時の法令, 1580 号, 56-70 (1998).

2)星野一正: 時の法令, 1582 号, 印刷中 (1998).

3)星野一正:時の法令, 1556 号, 62-68 (1997). 